\title{
Analysis of Monthly, Seasonal and Annual Air Temperature Variability and Trends in Taiz City - Republic of Yemen
}

\author{
Mahyoub H. Al Buhairi \\ Physics Department, Faculty of applied Science, Taiz University, Taiz, Yemen. \\ Email: albuhairi@hotmail.com
}

Received March 23 $3^{\text {rd }}, 2010$; revised August $9^{\text {th }}, 2010$; accepted August 15 ${ }^{\text {th }}, 2010$.

\begin{abstract}
Climate change is one of the most important issues of today's World. Climate scientists have concluded that the earth's surface air temperature warmed by $0.6 \pm 0.2^{\circ} \mathrm{C}$ during the $20^{\text {th }}$ century, accompanied by changes in the hydrologic cycle. Of all the climate elements, temperature plays a major role in detecting climate change brought about by urbanization and industrialization. This study focuses on the variability and trends of the mean annual, seasonal and monthly surface air temperature in Taiz city, Republic of Yemen, during the period 1979-2006. The results of the analysis of the whole period reveal a statistically significant increasing trend in practically all the months and seasons. A tendency has also been observed towards warmer years, with significantly warmer summer and spring periods and slightly warmer autumn and winter, an increase of $1.79^{\circ} \mathrm{C}$ and $1.18^{\circ} \mathrm{C}$ has been observed in the mean summer and mean winter temperature, respectively. Positive trends of about $1.5^{\circ} \mathrm{C}$ in the annual mean temperature were found for the whole period. The air temperature time series are analyzed, so that the variability and trends can be described.
\end{abstract}

Keywords: Air Temperature, Climate Change, Republic of Yemen, Taiz City, Mann-Kendall Test, Trends

\section{Introduction}

Climatic change is one of the most important issues of present times, therefore World-wide interest in global warming and climate change has led to numerous trend detection studies. Anthropogenic interference in the environment is one of the greatest causes of the process of climatic change in several regions of the world. This complex phenomenon, which includes natural and human processes, depends on a multiplicity of factors and is an almost irreversible scenario [1]. The Earth's atmosphere is warming and that human activities that release greenhouse gases are an important cause. Warming of the atmosphere affects the temperature of air, land, and water, which in turn affects patterns of precipitation, evaporation, and wind, as well as ocean temperature and currents. Greenhouse gases are atmospheric gases such as carbon dioxide, methane, and nitrous oxide. The concentration of $\mathrm{CO}_{2}$, one of the major greenhouse gases, in the atmosphere has increased significantly. They trap solar energy, warming the atmosphere and the surface of the Earth, and play a critical role in maintaining the tem- perature of the Earth within a range suitable for life. However, as the levels of these gases build up in the atmosphere, they act like the transparent roof of a greenhouse, which allows in sunlight while trapping the heat energy.

Climate change over the last century is a subject of great topical interest. This problem worries the scientific community, as it could have a major impact on natural and social systems at local, regional and national scales. Numerous climatologists [2,3]; Intergovernmental Panel on Climate Change (IPCC), [4-6] agree that there has been a large-scale warming of the Earth's surface over the last hundred years or so. This warming up of the Earth during the $20^{\text {th }}$ century brought with it a decrease in the area of the world affected by exceptionally cool temperatures, and, to a lesser extent, an increase in the area affected by exceptionnally warm temperatures [2]. Some analyses of long time-series of temperatures on a hemispheric and global scale [4] have indicated a warming rate of $0.3-0.6^{\circ} \mathrm{C}$ since the mid-19th century, due to either anthropogenic causes [4] or astronomic causes $[7,8]$. The Third Assessment Report projections for the 
present century are that average temperature rises by 2100 would be in the range of $1.4-5.8^{\circ} \mathrm{C}[4,9]$. Records show that global temperatures, averaged world-wide over the land and sea, rose $0.6 \pm 0.2^{\circ} \mathrm{C}$ during the 20th century. A number of recent studies have been devoted to global, hemispherical, or regional long-term temperature variations. On a global scale, climatological studies indicate an increase of $0.3-0.6^{\circ} \mathrm{C}$ of the surface air temperature $0.5-0.7^{\circ} \mathrm{C}$ for the Northern Hemisphere) since 1860 [2, $10,11]$, while the eighth warmest years ever recorded were observed after [12] .

A broad consensus of scientists has concluded that, the earth's surface air temperature increased by about $0.6^{\circ} \mathrm{C}$ during the 20th century, that most of the warming during the latter half of the century is attributable to human emissions of greenhouse gases, and that temperature increases were greatest during the 1990s [4]. Numerous other factors such as variations in solar radiation and pollutant aerosols also contribute to climate change $[13,14]$. The IPCC panel further concluded that global temperature increases are likely to persist in the $21 \mathrm{st}$ century and will probably be accompanied by changes in precipitation and runoff amounts. Future climate change is more difficult to predict with great certainty at the regional scale due to spatial resolution limitations of current climate models and to the likely influence of unaccounted for factors such as regional land use change [15].

The Republic of Yemen lies in the South of The Arabian Peninsula, south-west of Asia. South-West Asia (the Middle East), is a relatively data sparse region of the world. Rapid population growth and water scarcity are common throughout the area, rendering it sensitive to changes in climate. This emphasizes the importance of meteorological data and climatic knowledge to the region. In the Middle East, investigations of long-term variations and trends in temperature data are not receiving enough attention even though, these countries suffer serious environmental, agricultural and water resources problems. The dominating climatic feature in the region is the summer Southwest Asian Monsoon, which influences the climatology of the nations within the subregion to varying degrees and in diverse ways [4]. Climate trends and variability in Asia are generally characterized by increasing surface air temperature which is more pronounced during winter than in summer. The observed increases in some parts of Asia during recent decades ranged between less than $1{ }^{\circ} \mathrm{C}$ to $3^{\circ} \mathrm{C}$ per century. Increases in surface temperature are most pronounced in North Asia [16]; Climate Change in Russia [17,18].

The Third Assessment Report predicted that the area-averaged annual mean warming would be about $3^{\circ} \mathrm{C}$ in the decade of the $2050 \mathrm{~s}$ and about $5^{\circ} \mathrm{C}$ in the dec- ade of the 2080s over the land regions of Asia as a result of future increases in atmospheric concentration of greenhouse gases [19]. The rise in surface air temperature was projected to be most pronounced over boreal Asia in all seasons. Many investigators have studied climatic changes in various regions of the world including: United States [20-24]; Philippines [25]; Europe [26,27]; Kenya [28]; Arab Region [29-33]; Taiwan [34,35]; Israel [36]; and Italy [37]. Thus, given the relevance of the climate change in the world, the present paper aimed to ascertain the occurrence of climatic variability in Taiz City, which is considered one of the largest cities in Yemen, which lies to the north west of the Yemeni Republic. The climate in Yemen is various and depends on the different altitudes of the regions. There are no distinctive limits between the seasons. Generally there are two main seasons; summer and winter. During summer the climate is hot with high humidity dominating in the coastal area. In winter the climate in the coastal area is relatively moderate. Occasional rains in the summer are caused by the monsoon coming from the Indian Ocean. These rains decrease the high temperatures in the coastal area during the summer. The weather in the mountain area is moderate in summer and relatively cold in winter. During winter it becomes especially cold in the night and in the early morning, with pleasant sunny days.

In this study, the variability and trends of the monthly mean, mean annual and seasonal surface air temperature in Taiz are examined. The climatic data used concern mean monthly values of air temperature Meteorological Service, for the period 1979-2006. The air temperature time series are analyzed, so that the variability and trends be described. The monthly, seasonal and annual temperature trends of mean, mean maximum, and mean minimum air temperature are discussed. The work then focuses on the statistics of the annual, seasonal and monthly maximum, minimum and mean temperatures.

\section{Methods}

\subsection{Study Area}

Taiz city is one of the largest cities in Yemen located in the southwest of Yemen (located at $13^{\circ} 35^{\prime} \mathrm{N}$ and $44^{\circ} 01^{\prime}$ E). Its average height from sea level is $1311 \mathrm{~m}$.

Daily air temperature data during the period 19792006, were obtained from agro meteorological station of the Agricultural Research and Extension Authority (AREA) in Taiz. The station elevation is $1200 \mathrm{~m}$ above sea level with latitude N $13^{\circ} 42^{\prime}$ and longitude E $44^{\circ} 55^{\prime}$. The mean annual rainfall and temperature is $588 \mathrm{~mm}$ and $24^{\circ} \mathrm{C}$, respectively, while the mean monthly evaporation is $140 \mathrm{~mm}$. The geographical location of Yemen and the 
Osiefera station in Taiz City provide a sign and indication about temperature changes and trends in the region.

For the purpose of this study, the uninterrupted temperature series from 1979 to 2006 has been used, consisting of maximum and minimum air temperatures measured with thermometers. The readings, maximum and minimum, are averaged for the calculation of monthly, seasonal and annual temperatures.

Daily air temperature data were first calculated as monthly maximum, minimum, and mean temperature. Monthly temperature values were averaged to obtain seasonal and annual values.

Trends were determined using the computer's program template. This template uses a nonparametric MannKendall test to assess the probability that there is a trend statistically different from zero, and evaluate increasing or decreasing slope of trends in the climate variables.

\subsection{Trend Detection}

Trends were detected in the time series of all the indices analysed by means of the Mann-Kendall test $[38,39]$. This is a rank correlation statistic test based on the comparison of the observed number of discordances and the value of the same quantity expected from a random series. The Mann-Kendall method has been suggested by the World Meteorological Organization to assess the trend in environmental data time-series [35]. This test consists of comparing each value of the time-series with the others remaining, always in sequential order. The number of times that the remaining terms are greater than that under analysis is counted [40,41]. The Mann-Kendall statistic is given by:

$$
S=\sum_{i=2}^{n} \sum_{j=1}^{i-1} \operatorname{sign}\left(x_{i}-x_{j}\right)
$$

where $n$ is the length of the data set, $x_{i}$ and $x_{j}$ are two generic sequential data values, and the function $\operatorname{sign}\left(x_{i}-x_{j}\right)$ assumes the following values:

$$
\operatorname{sign}\left(x_{i}-x_{j}\right)=\left\{\begin{array}{c}
1, \text { if }\left(x_{i}-x_{j}\right)>0, \\
0, \text { if }\left(x_{i}-x_{j}\right)=0, \\
-1, \text { if }\left(x_{i}-x_{j}\right)<0 .
\end{array}\right.
$$

The $S$ statistic therefore represents the number of positive differences minus the number of negative differences found in analyzed time series. Under the null of that there is no trend in the data no correlation between considered variable and time, each ordering of the data set is equally likely. Under this hypothesis the statistic $S$ is approximately normally distributed with the mean $E(S)$ and the variance $\operatorname{Var}(S)$ as follows:

$$
E(S)=0
$$

$$
\operatorname{Var}(S)=\frac{1}{18}\left[n(n-1)(2 n=5)-\sum_{p=1}^{q} t_{p}\left(t_{p}-1\right)\left(2 t_{p}+5\right)\right]
$$

where $n$ is the length of the times-series, $t_{p}$ is the number of ties for the $p^{\text {th }}$ value and $q$ is the number of tied values i.e., equals values. The second term represents an adjustment for tied or censored data. The standardized test statistic $Z$ is given by:

$$
Z=\left\{\begin{array}{cc}
\frac{S-1}{\sqrt{\operatorname{Var}(S)}} \quad \text { if } S>0, \\
0 & \text { if } S=0, \\
\frac{S-1}{\sqrt{\operatorname{Var}(S)}} & \text { if } \quad S<0 .
\end{array}\right.
$$

The presence of a statistically significant trend is evaluated using the $Z$ value. This statistic is used to test the null hypothesis such that no trend exists. A positive $Z$ indicates an increasing trend in the time-series, while a negative $Z$ indicates a decreasing trend. To test for either increasing or decreasing monotonic trend at $p$ significance level, the null hypothesis is rejected if the absolute value of $Z$ is greater than $Z_{(1-p / 2)}$; where $Z_{(1-p / 2)}$ is obtained from the standard normal cumulative distribution tables. In this work, the significance levels of $0.01,0.05$ and 0.1 were applied, and the significant level p-value was obtained for each analyzed time-series. It is also possible to obtain a non-parametric estimate for the magnitude of the slope of trend [42].

$$
b=\text { Median }\left[\frac{\left(X_{j}-X_{i}\right)}{(j-i)}\right], \text { for all } i<j
$$

where is the slope between data points $X_{j}$ and $X_{i}$; measured at times $j$ and $i$; respectively.

\section{Results and Discussion}

The standard deviation $(\sigma)$ and mean $(\mu)$ of the maximum (Tmax), minimum (Tmin) and mean (Tmean) temperatures are specified in Table 1. From the basic temperature data, (Tmax), (Tmin) and (Tmean) temperature, along with their standard deviation $(\sigma)$ have been statistically computed for each month, year and the four seasons; spring, summer, autumn, and winter. These means are depicted in Table 1. Seasons were defined using the standard meteorological definition: winter $=$ December, January and February, spring = March, April and May; summer $=$ June, July and August and autumn $=$ September, October and November.

Table 1 reports the temperature characterrristics in Taiz city. It is clear from the Table that, the mean monthly temperature is highest in June $26.6^{\circ} \mathrm{C}$ and lowest 
Table 1. Statistics of the monthly, seasonal and annual temperature means $(\mu)$ and standard deviation $(\sigma)$.

\begin{tabular}{|c|c|c|c|c|c|c|}
\hline \multirow{2}{*}{ Month } & \multicolumn{2}{|c|}{$\mathrm{T}_{\max .}\left({ }^{\circ} \mathrm{C}\right)$} & \multicolumn{2}{|c|}{$\mathrm{T}_{\min } \cdot\left({ }^{\circ} \mathrm{C}\right)$} & \multicolumn{2}{|c|}{$\mathrm{T}_{\text {mean }}\left({ }^{\circ} \mathrm{C}\right)$} \\
\hline & $\mu$ & $\sigma$ & $\mu$ & $\sigma$ & $\mu$ & $\sigma$ \\
\hline January & 27.3 & 0.88 & 14.1 & 2.02 & 20.7 & 1.15 \\
\hline February & 28.4 & 1.28 & 15.3 & 2.02 & 21.8 & 1.19 \\
\hline March & 29.9 & 1.10 & 17.3 & 1.61 & 23.6 & 1.08 \\
\hline April & 31.3 & 1.42 & 18.8 & 1.67 & 25.1 & 1.28 \\
\hline May & 32.9 & 1.23 & 19.5 & 2.03 & 26.2 & 1.36 \\
\hline June & 33.3 & 0.80 & 19.9 & 1.45 & 26.6 & 0.98 \\
\hline July & 32.5 & 0.82 & 20.2 & 1.91 & 26.3 & 1.16 \\
\hline August & 32.0 & 0.56 & 19.1 & 2.13 & 25.6 & 1.14 \\
\hline September & 31.8 & 1.15 & 17.8 & 2.06 & 24.8 & 1.36 \\
\hline October & 31.1 & 0.92 & 16.9 & 1.81 & 23.9 & 1.13 \\
\hline November & 29.6 & 0.90 & 15.7 & 1.50 & 22.7 & 0.89 \\
\hline December & 28.1 & 0.97 & 14.9 & 1.90 & 21.5 & 0.83 \\
\hline Annual & 30.7 & 0.58 & 17.5 & 1.44 & 24.1 & 0.84 \\
\hline Spring & 31.4 & 1.07 & 18.6 & 1.61 & 25 & 1.12 \\
\hline Summer & 32.6 & 0.75 & 19.8 & 1.74 & 26.2 & 1.00 \\
\hline Autumn & 30.8 & 0.8 & 16.8 & 1.50 & 23.8 & 0.95 \\
\hline Winter & 27.9 & 0.81 & 14.8 & 1.67 & 21.3 & 0.81 \\
\hline
\end{tabular}

in January $20.7^{\circ} \mathrm{C}$. However, the mean maximum temperature for June is $33.3^{\circ} \mathrm{C}$. On the average, January is the coldest month of the year and June is the warmest (only slightly warmer than May and July). The lowest mean monthly temperature occurred in January 1987 $\left(8.7^{\circ} \mathrm{C}\right)$ and the warmest month ever recorded was May $1999\left(35.2^{\circ} \mathrm{C}\right)$. The temperature variability between the different years and the average annual temperature is $24.1^{\circ} \mathrm{C}$, while the annual mean maximum temperature reached $30.7^{\circ} \mathrm{C}$ and the annual mean minimum temperature was $17.5^{\circ} \mathrm{C}$.

The Mann-Kendall test statistics of the Tmax, Tmin, and Tmean are given in Table $\mathbf{2}$. The statistically significant levels, high 0.01 , medium 0.05 and low 0.1 were used in this paper [1]. The nonparametric estimate for the magnitude of the slope, $b$, was computed for the significant trends, which certify all the trends in ${ }^{\circ} \mathrm{C} /$ year. Table 1 reports the temperature characteristics in Taiz city. It is clear from the Table that, the mean monthly temperature is highest in June $26.6^{\circ} \mathrm{C}$ and lowest in January $20.7^{\circ} \mathrm{C}$. However, the mean maximum temperature for June is $33.3^{\circ} \mathrm{C}$. On the average, January is the coldest month of the year and June is the warmest (only slightly warmer than May and July). The lowest mean monthly temperature occurred in January $1987\left(8.7^{\circ} \mathrm{C}\right)$ and the warmest month ever recorded was May $1999\left(35.2^{\circ} \mathrm{C}\right)$. The temperature variability between the different years and the average annual temperature is $24.1^{\circ} \mathrm{C}$, while the annual mean maximum temperature reached $30.7^{\circ} \mathrm{C}$ and the annual mean minimum temperature was $17.5^{\circ} \mathrm{C}$.

The Mann-Kendall test statistics of the Tmax, Tmin, and Tmean are given in Table 2. The statistically significant levels, high 0.01 , medium 0.05 and low 0.1 were used in this paper. The nonparametric estimate for the magnitude of the slope, $b$, was computed for the significant trends, which certify all the trends in ${ }^{\circ} \mathrm{C} /$ year.

Behavior of the Tmax, Tmin, and Tmean was studied for individual months, seasons and annually by subjecting them to the Mann-Kendall test. The results of the standardized test statistics $\mathrm{Z}$, significance level $p$-value and the slope $b$; corresponding to the temperature variables trend analysed in this study are presented in Table 2. It is to be noted have that the Tmax and Tmean shows a significant trend in the majority of the months, while Tmin shows a significant trend in nearly half the number of the months. 
Table 2. Mann-Kendall trend test results ( $\mathrm{Z}$ and $p$-value) and the slope $b$.

\begin{tabular}{|c|c|c|c|c|c|c|c|c|c|}
\hline \multirow{2}{*}{ Month } & \multicolumn{3}{|c|}{ Tmax } & \multicolumn{3}{|c|}{ Tmin } & \multicolumn{3}{|c|}{ Tmean } \\
\hline & Z & $P$-value & $b\left({ }^{\circ} \mathrm{C} /\right.$ Year $)$ & $Z$ & $P$-value & $b\left({ }^{\circ} \mathrm{C} /\right.$ Year $)$ & $Z$ & $P$-value & $b\left({ }^{\circ} \mathrm{C} /\right.$ Year $)$ \\
\hline January & 1.73 & 0.084 & 0.037 & 0.97 & 0.33 & 0.026 & 2.14 & 0.033 & 0.038 \\
\hline February & 2.43 & 0.014 & 0.074 & 0.00 & 1 & 0.00 & 2.26 & 0.024 & 0.073 \\
\hline March & 2.99 & 0.003 & 0.071 & 0.98 & 0.84 & 0.009 & 2.20 & 0.03 & 0.041 \\
\hline April & 2.14 & 0.03 & 0.075 & 1.48 & 0.14 & 0.043 & 2.04 & 0.042 & 0.066 \\
\hline May & 3.43 & 0.001 & 0.105 & 2.08 & 0.04 & 0.067 & 2.87 & 0.004 & 0.088 \\
\hline June & 2.98 & 0.003 & 0.056 & 2.24 & 0.025 & 0.071 & 2.53 & 0.011 & 0.064 \\
\hline July & 2.99 & 0.003 & 0.06 & 3.19 & 0.0014 & 0.097 & 4.01 & 0.0001 & 0.092 \\
\hline August & 1.89 & 0.059 & 0.029 & 0.83 & 0.41 & 0.032 & 2.23 & 0.026 & 0.031 \\
\hline September & 1.68 & 0.092 & 0.033 & 1.99 & 0.046 & 0.091 & 2.10 & 0.038 & 0.057 \\
\hline October & 1.19 & 0.23 & 0.026 & -0.099 & 0.92 & 0.00 & 0.97 & 0.33 & 0.021 \\
\hline November & 2.73 & 0.006 & 0.06 & 1.54 & 0.12 & 0.05 & 2.57 & 0.01 & 0.058 \\
\hline December & 2.42 & 0.015 & 0.05 & -0.06 & 0.95 & 0.00 & 1.84 & 0.066 & 0.031 \\
\hline Annual & 8.32 & 0.000 & 0.05 & 4.19 & 0.11 & 0.042 & 8.07 & 0.000 & 0.053 \\
\hline Spring & 4.96 & 0.0002 & 0.084 & 2.19 & 0.03 & 0.04 & 4.12 & 0.000 & 0.064 \\
\hline Summer & 4.56 & 0.0002 & 0.044 & 3.63 & 0.0003 & 0.067 & 5.10 & 0.000 & 0.064 \\
\hline Autumn & 3.26 & 0.014 & 0.04 & 1.99 & 0.05 & 0.047 & 3.27 & 0.001 & 0.045 \\
\hline Winter & 3.82 & 0.003 & 0.05 & 0.53 & 0.60 & 0.0098 & 3.62 & 0.0003 & 0.042 \\
\hline
\end{tabular}

\subsection{Annual Temperature Trends}

The annual mean, annual maximum and annual minimum temperatures and trend line are presented in Figure 1. The Mann-Kendall test confirmed that the positive trend observed is statistically significant see Table 2 . The mean annual temperature and the mean annual maximum temperature show an increasing trend, which is statistically significant at $P<0.01$ level, while the mean annual minimum temperature is significant at 0.1 level. A linear fit to the ensemble averaged annual means of mean, minimum and maximum temperature anomalies confirms significant and quite large trends of $0.053^{\circ} \mathrm{C}$ /year for mean temperatures. This trend corresponds to an increase of $1.5^{\circ} \mathrm{C}$ in the total period analysed (1979-2006) of mean temperature. The annual mean maximum air temperatures trend is that of $0.05^{\circ} \mathrm{C} /$ year. This trend corresponds to an increase of $1.4^{\circ} \mathrm{C}$ in the total period analyzed of mean maximum temperature. Annual mean minimum temperature trend was a little less $0.042^{\circ} \mathrm{C} /$ year. The temperature increase corresponding to the total period was $1.2^{\circ} \mathrm{C}$ of annual mean minimum temperature.

\subsection{Seasonal Temperature Trends}

In the climatic seasons we observe a different tendency of changes in air temperature. The mean temperature, Tmax and Tmin for spring, summer, autumn and winter seasons during the period 1979-2006 are presented in Figure 2. The parameters analysed show a positive trend practically for all seasons and is most important for maximum temperatures Table 2. The air temperature time-series in Taiz for the whole period analysed showed an increasing trend statistically significant at $P<0.01, P$ $<0.05$ and $P<0.1$ in practically all the months and seasons. However, some months showed a declining trend February, October and December.

The winter mean temperature shows an increasing trend, which is statistically significant at $P<0.01$ level Table 2. Tmin also shows warming. However, this warming trend of Tmin is not statistically significant. The Tmax during winter shows an increasing trend, which is statistically significant at $P<0.01$. In spring the MannKendall test indicates that the mean temperature shows an increasing trend, significant at $P<0.01$ level. Tmax also shows an increasing trend, significant at $P<0.01$ 

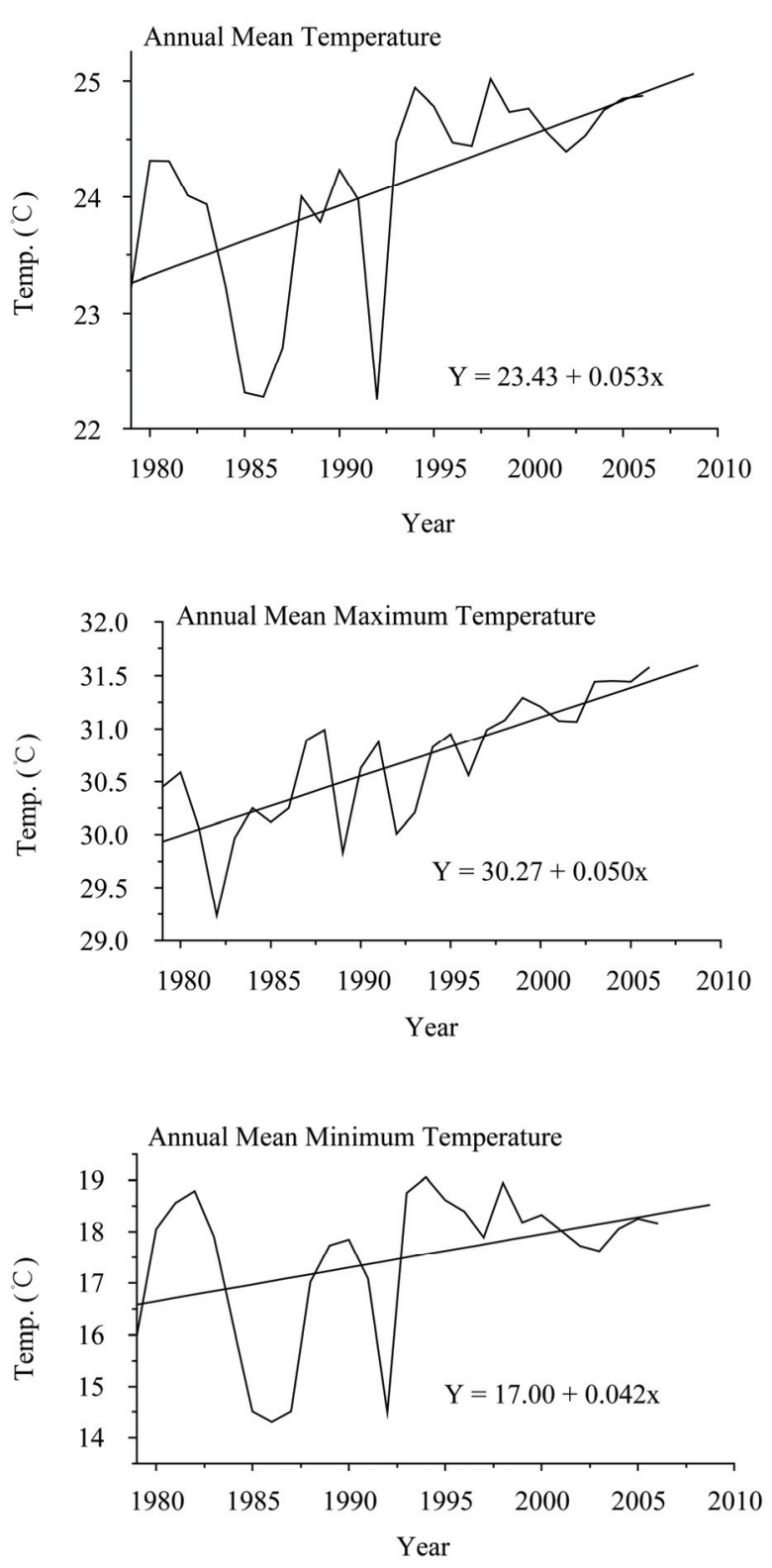

Figure 1. Annual temperature trends in Taiz.

level and Tmin shows an increasing trend, which is statistically significant at $P<0.05$ level.

The summer mean temperature, Tmax and Tmin also shows an increasing trend, significant at $P<0.01$ level. Autumn is characterized by a significant increase in temperature. The mean and mean maximum temperature show an increasing trend, which is statistically significant at $P<0.01$ level. The mean minimum also shows an increasing trend, significant at $P<0.05$ level.

\subsection{Monthly Temperature Trends}

Behavior of mean, mean minimum and mean maximum temperature was also studied for individual months by subjecting them to the Mann-Kendall test. The results are presented also in Table 2. The mean temperature shows a significant trend practically for all months except October. Statistically significant at the $P<0.05$ level increases in mean air temperature were noted for January, February, March, April, August and September. However, this increase is significant for May, June, July and November at $P<0.01$ level and December at 0.1 level.

Tmax shows a significant trend practically for all months except October. Statistically significant at the level 0.01 increases in maximum air temperature were noted for February, March, May, June, July, November and December. However, this increase is significant for January, April, August and September at 0.05 level. April, May and July showed the greatest increasing trend in the mean maximum air temperature in the whole period analysed. Tmin also shows a significant trend in the majority of the months. The trend analysis of winter months shows an increasing trend in minimum temperature, which is not statistically significant. The T $\min$ at the beginning of spring, though it shows an increasing trend in minimum temperature, is not statistically significant. The later part of spring, particularly April and May, shows an increasing trend significant for April at 0.1 level and May at 0.05 level. The trend of Tmin during the summer months shows an increasing trend significant for June at 0.05 level, July at 0.01 level and August are not statistically significant. The mean minimum temperature during the autumn months shows an increasing trend significant for November at 0.1 level, while October and December are not statistically significant.

This increase in temperature is attributed to the green house gases emissions, especially $\mathrm{CO}_{2}$, from the different motor vehicles used in the city. The rough terrain of the city, as the city is an area that is shaped ridges, depressions and dissecting wadis, leads to only partial combustion of the fuel which, in its turn, leads to an increase in the effort of the engine. The factories situated around the city as well the increase in human activities and the dearth of green areas and parks in the city also contribute to the warming of the city. Moreover, the mountains which surround the city, especially Saber Mountain which is bout 3100 meters above sea level, act like natural wind shields preventing smooth circulation of air and leading to an increase in the warming of the city.

\section{Conclusions}

This study investigated monthly, seasonal and annual climatic variability in Taiz City based on mean maximum, mean minimum and mean air temperatures. One of the main results of this study is the confirmation of a significant warming trend in average temperatures in 

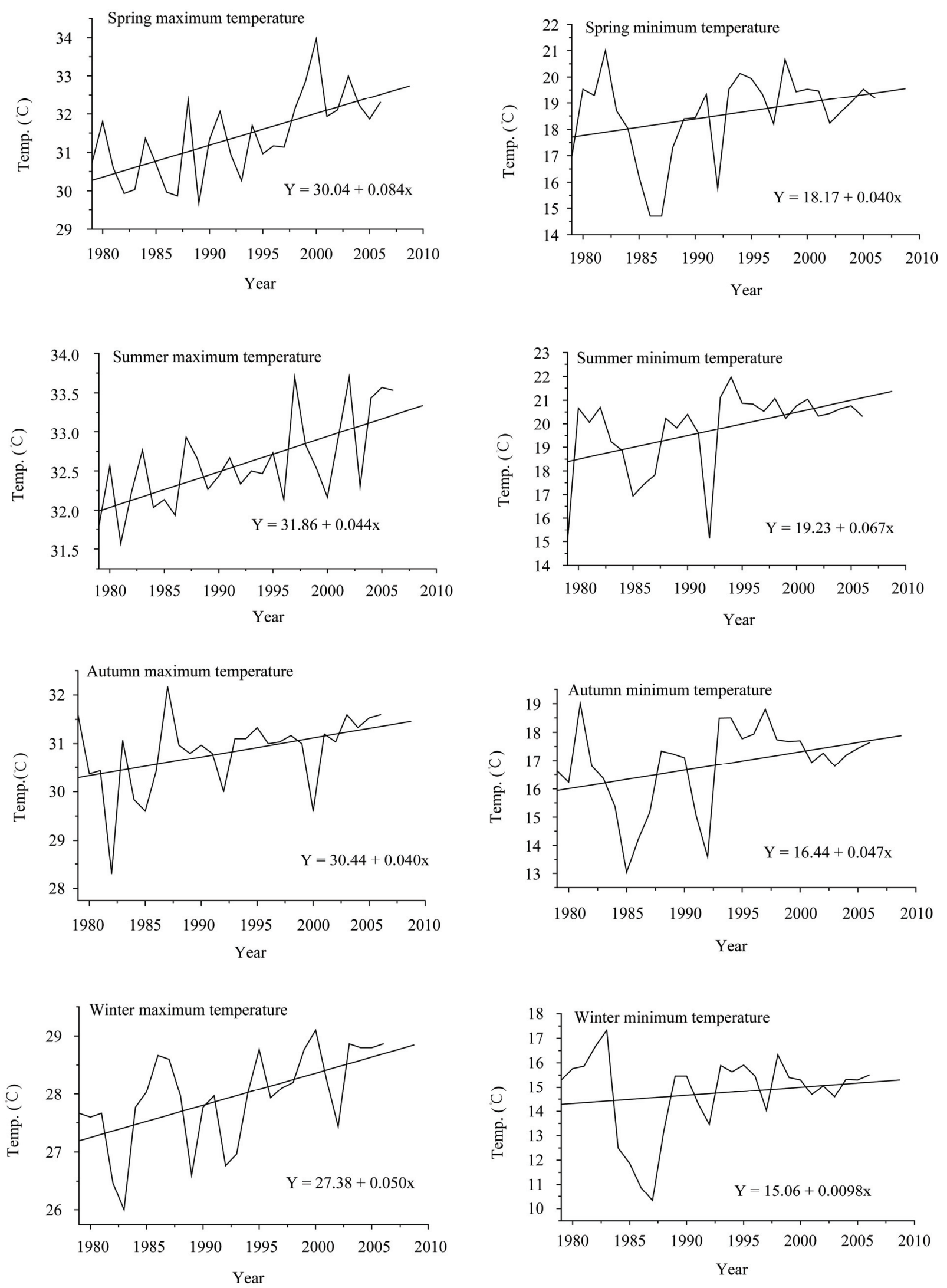

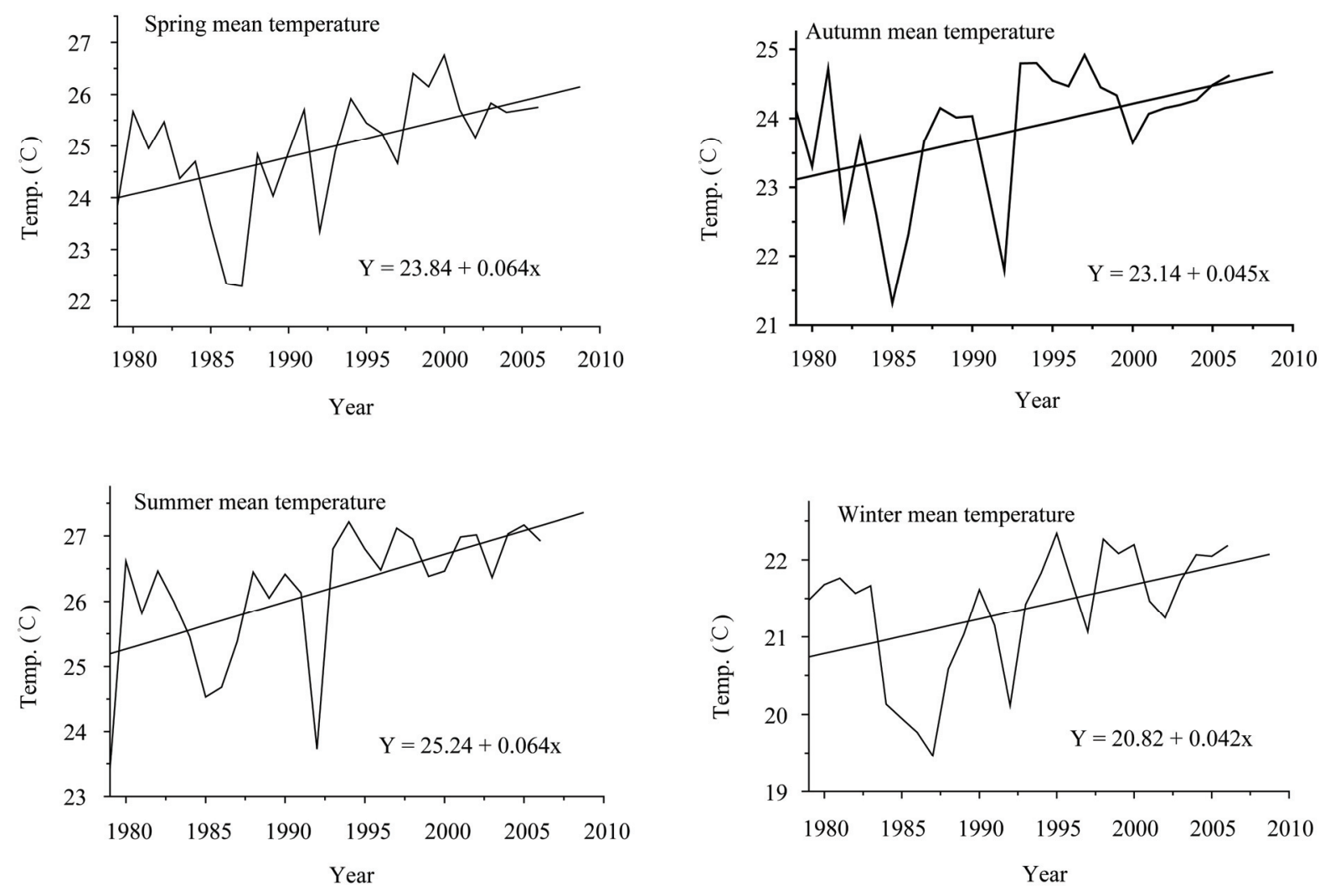

Figure 2. Temperature trends for spring, summer, autumn and winter in Taiz.

Taiz city, of about $1.5^{\circ} \mathrm{C}$ in the past 30 years, concentrated in spring and summer months. Analysis of maximum and minimum temperatures reveals a warming trend for the annual and all seasonal series. The warming trend for the summer and winter seasons is statistically significant at $P<0.01$ level with a rate of increase of $0.064^{\circ} \mathrm{C} /$ year, $0.042^{\circ} \mathrm{C} /$ year, respectively.

\section{REFERENCES}

[1] V. P. R. Silva, "On Climate Variability in North-East of Brazil," Journal of Arid Environments, Vol. 58, No. 4, 2004, pp. 575-596.

[2] P. D. Jones, E. B. Horton, C. K. Folland, M. Hulme, D. E. Parker and T. A. Basnett, "The Use of Indices to Identify Changes in Climatic Extremes," Climatic Change, Vol. 42, No. 1, 1999, pp. 131-149.

[3] D. E. Parker and E. B. Horton, "Global and Regional Climate in 1998," Weather, Vol. 54, 1999, pp. 173-184.

[4] Inter Governmental Panel on Climte Change (IPCC), "Climate Change 2001: Synthesis Report, Contribution of Working Groups I and III to the Third Assessement of the (IPCC)," Cambridge University Press, Cambridge, 2001.

[5] P. D. Jones and A. Moberg, "Hemispheric and LargeScale Surface Air Temperature Variations: An Extensive Revision and Update to 2001," Journal Climate, Vol. 16,
2003, pp. 206-223.

[6] K. Y. Vinnikov and N. C. Grody, "Global Warming Trend of Mean Tropospheric Temperature Observed by Satellites," Science, Vol. 302, 2003, pp. 269-272.

[7] W. Soon, S. Baliunas, E. S. Posmentier and P. Okeke, "Variations of Solar Coronal Hole Area and Terrestrial Lower Tropospheric Air Temperature from 1979 to Mid-1998: Astronomical Forcings of Change in Earth'S Climate," New Astron, Vol. 4, No. 8, 2000, pp. 563-579.

[8] T. Landscheidt, "Solar Wind near Earth: Indicator of Variations in Global Temperature," Proceedings of the 1st Solar and Space Weather Euroconference on the Solar Cycle and Terrestrial Climate, Tenerife, 2000, pp. 497-500.

[9] IPCC, "Climate Change 2001: Impacts, Adaptation and Vulnerability," In: J. McCarthy, O. Canziani, N. Leary, D. Dokken and K. White, Eds., Contribution of Working Group II to the Third Assessment Report of the (IPCC), World Meteorological Organisation and United Nations Environment Programme, Cambridge University Press, Cambridge, 2001.

[10] P. D. Jones, T. M. L. Wigley and P. B. Wright, "Global Temperature Variations between 1861 and 1984," Nature, Vol. 322, 1986, pp. 430-434.

[11] P. D. Jones, "Hemispheric Surface Air Temperature Variations: Recent Trends and an Update to 1987," Journal of Climate Vol. 1, 1988, pp. 654-660. 
[12] WMO, "WMO Statement on the Status of the Global Climate in 1996," WMO, No. 858, World Meteorological Organization, Geneva, 1997.

[13] G. P. Brasseur and E. Roeckner, "Impact of Improved Air quality on the Future Evolution of Climate," Geophysical Research Letters Vol. 32, No. L23704, 2005, p. 4

[14] N. Scafetta and B. J. West, "Estimated Solar Contribution to the Global Surface Warming Using the ACRIM TSI Satellite Composite," Geophysical Research Letters, Vol. 32, 2005, p. L18713.

[15] R. A. Pielke, "Land Use and Climate Change," Science, Vol. 310, No. 5754, 2005, pp. 1625-1626.

[16] I. P. Savelieva, L. N. Semiletov, Vasilevskaya and S. P. Pugach, "A Climate Shift in Seasonal Values of Meteorological and Hydro Logical Parameters for Northeastern Asia," Progress in Oceanography, Vol. 47, No. 2, 2000, pp. 279-297.

[17] Climate Change in Russia, IGCE Rusian Agency on Hydrometeorology and Environmental Monitoring Publishing, Moscow, 2003.

[18] G. Gruza and E. Rankova, "Detection of Changes in Climate State, Climate Variability and Climate Extremity," Institute of Global Climate and Ecology, Moscow, No. 4, 2004, pp. 90-93.

[19] M. Lal, H. Harasawa, D. Murdiyarso, W. N. Adger, S. Adhikary, M. Ando, Y. Anokhin, R. V. Cruz, et al., "Asia Climate Change (2001): Impacts, Adaptation, and Vulnerability Contribution of Working Group II to the Third Assessment Report of the IPCC, J. J. Mc- and K. S. White, Eds., Cambridge University Press, Cambridge, 2001(a).

[20] R. C. Balling Jr. and S. W. Brazel, "The Impact of Rapid Urbanization on Pan Evaporation in Phoenix, Arizona," Journal of Climatology, Vol. 7, No. 6, 1987, pp. 593-597.

[21] A. C. Comrie, and B. Broyles, "Variability and Spatial Modeling of Fine-Scale Precipitation Data for the Sonoran Desert of South-West Arizona," Journal of Arid Environments, Vol. 50, No. 4, 2002, pp. 573-592.

[22] C. K. Folland, C. Miller, D. Bader, M. Crowe, P. Jones, N Plummer, M. Richman, D. E. Parker, J. Rogers and P. Scholefield, "Work Shop in Indices and Indicators for Climate Extremes," Geophysical Research Letters, Vol. 32, 1997, p. L18713.

[23] D. R. Easterling, H. F. Diaz, A. V. Douglas, W. D. Hogg, K. E. Kunkel, J. C. Rogers and J. F. Wilkinson, "LongTerm Observations for Monitoring Extremes in the Americas," Climatic Change, Vol. 42, 1999, pp. 285-308.

[24] T. R. Karl and D. R. Easterling, "Climate Extremes: Selected review and Future Research Directions," Climatic Change, Vol. 42, No. 1, 1999, pp. 309-325.

[25] A. M. Jose, R. V. Francisco and N. A. Cruz, "A Study on Impact of Climate Variability Change on Water Resources in the Philippines," Chemosphere, Vol. 33, No. 9, 1996, pp. 1687-1704.

[26] N. W. Arnell, "The Effect of Climate Change on Hydrological Regimes in Europe: A Continental Perspective," Global Environmental Change, Vol. 9, No. 1, 1999, pp. $5-23$.
[27] A. A. Velichkov, N. Catto, A. N. Drenova, V. A. Klimanov and K. V. Kremenetski, "Climate Change in East Europe and Siberia at the Late Glacial-Holocene Transition," Quaternary International, Vol. 91, No. 1, 2002, pp. 75-99.

[28] E. C. Kipkorir, "Analysis of Rainfall Climate on the Njemps Flats, Baringo District, Kenya," Journal of Arid Environments, Vol. 50, No. 3, 2002, pp. 445-458.

[29] S. Al-Fahed, O. Al-Hawaj and W. Chakroun, "The Recent Air Temperature Rise in Kuwait," Renewable Energy, Vol. 12, No. 1, 1997, pp. 83-90.

[30] N. A. Elagib and A. S. Abdu, "Climate Variability and Aridity in Bahrain," Journal of Arid Environmental, Vol. 36, No. 3, 1997, pp. 405-419.

[31] A. A. Abahussain, A. S. Abdu, W. K. Al-Zubari, N. A. El-Deen and M. Abdul-Raheem, "Desertification in the Arab Region: Analysis of Current Status and Trends," Journal of Arid Environments, Vol. 51, No. 4, 2002, pp. 521-545.

[32] M. S. Mahmoud and Z. Ahmed, "A Sudden Change in Rainfall Characteristics in Amman, Jordan during the Mid 1950s," American Journal of Environmental Sciences, Vol. 2, No. 3, 2006, pp. 84-91.

[33] M. S. Mahmoud, "Observed Abrupt Changes in Minimum and Maximum Temperatures in Jordan in the 20th Century," American Journal of Environmental Sciences, Vol. 2, No. 3, 2006, pp. 114-120.

[34] C. C. Chang, "The Potential Impact of Climate Change on Taiwan's Agriculture," Agricultural Economics Vol. 27, No. 3, 2002, pp. 51-64.

[35] P. S. Yu, T. C. Yang and C. K. Wu, "Impact of Climate Change on Water Resources in Southern Taiwan," Journal of Hydrology, Vol. 260, 2002, pp. 161-175.

[36] S. Cohen, A. Ianetz, and G. Stanhill, "Evaporative Climate Change at Bet Dagan, Israel, 1964-1998," Agricultural and Forest Meteorology, Vol. 111, No. 2, 2002, pp. 83-91.

[37] A. C. Moonen, L. Ercoli, M. Mariotti and A. Masoni, "Climate Change in Italy Indicated by Agrometeorological Indices over 122 Years," Agricultural and Forest Meteorology, Vol. 111, No. 1, 2002, pp. 13-27.

[38] H. B. Mann, "Nonparametric Tests against Trend," Econometrica, Vol. 13, No. 3, 1945, pp. 245-259.

[39] M. G. Kendall, "Rank Correlation Measures," Charles Griffin, London, 1975.

[40] D. P. Lettenmaier, E. F. Wood and J. R. Wallis, "Hydroclimatological Trends in the Continental United States 1948-1988," Journal Climate, Vol. 7, 1994, pp. 586-607.

[41] H. B. Burn and M. A. H. Elnur, "Detection of Hydrologic Trends and Variability," Journal of Hydrology, Vol. 255, 2002, pp. 107-122.

[42] R. M. Hirsch, J. R. Slack and R. A. Smith, "Techniques of Trend Analysis for Monthly Water Quality Data," $W a$ ter Resources Research, Vol. 18, No. 1, 1982, pp. 107121. 